Пространственная Экономика

2013. № 4. C. 107-121

УДК 314:332

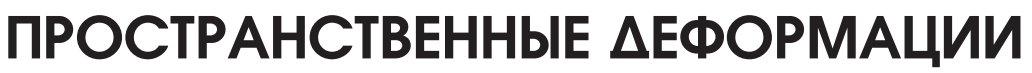 РЕЗУАЬТАТИВНОСТИ СИСТЕМЫ

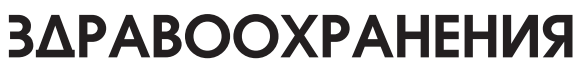

\author{
М.А. Грицко, Е.О. Колбина
}

Грицко Мария Анатольевна - кандидат экономических наук, научный сотрудник. Институт экономических исследований ДВО РАН, ул. Тихоокеанская, 153, Хабаровск, Россия, 680042. E-mail: gritsko@ecrin.ru.

Колбина Екатерина Олеговна - кандидат экономических наук, научный сотрудник. Институт экономических исследований ДВО РАН, ул. Тихоокеанская, 153, Хабаровск, Россия, 680042. E-mail: skripnikk@gmail.com.

На основе данных официальной статистики дана оценка результативности системы здравоохранения в разрезе федеральных округов РФ. Показано, что при более высоком уровне финансирования результативность системы здравоохранения в Дальневосточном федеральном округе (ДФО) остается самой низкой в стране как по абсолютным показателям, так и по темпам их изменения. Низкая результативность объясняется наличием системы ограничений: демографических, социально-экономических и пространственных. Проведенный анализ позволяет предположить, что, во-первых, игнорирование этих ограничений формирует искаженные представления о реальной ситуации в этом сегменте экономики; во-вторых, использование единой для всех регионов модели здравоохранения приводит к снижению ценовой и пространственной доступности медицинских услуг для населения, невозможности достижения целевых показателей в сфере здоровья населения и, в конечном счете, к неэффективному использованию государственных средств.

Результативность функционирования здравоохранения, продолжительность жизни, младенческая смертность, смертность мужчин трудоспособного возраста, система ограничений, ценовая доступность, пространственная доступность.

Основной целью функционирования системы здравоохранения является улучшение показателей здоровья населения. В качестве интегральной оценки результативности ее функционирования, а также и уровня социально-экономического развития страны можно рассматривать показатель продолжительности жизни, отражающий: эффективность вложения средств, выделяемых на здравоохранение; их распределение с учетом медико-демографических

(C) Грицко М.А., Колбина Е.О., 2013

Работа выполнена при поддержке проектов ДВО РАН № 13-ІІІ-В-10-210, № 12-I-П35-01. 
№ 42013

показателей; уровень соблюдения равных прав граждан на медицинскую помощь; удовлетворение потребностей населения в медицинских услугах; обеспеченность населения врачебными кадрами, средним медицинским персоналом, медицинскими учреждениями; развитие науки и внедрение научных достижений в практику здравоохранения и т. д. [5; 16].

Однако положительную траекторию изменения продолжительности жизни за последнее десятилетие, характерную для всех регионов Российской Федерации, нельзя оценивать однозначно (табл. 1). Несмотря на значимый рост абсолютных значений, скорость этих изменений недостаточна для достижения уровня продолжительности жизни населения развитых стран.

Продолжительность жизни для обоих полов, лет

Таблица 1

\begin{tabular}{l|c|c|c|c|c}
\hline \multicolumn{1}{c|}{ Территория } & 2000 & 2005 & 2011 & $2011 / 2000, \%$ & $2011-2002$, лет \\
\hline РФ & 65,27 & 65,37 & 69,83 & 1,07 & 4,56 \\
\hline ЦФО & 65,53 & 66,50 & 71,19 & 1,09 & 5,66 \\
\hline СЗФО & 64,74 & 64,17 & 70,07 & 1,08 & 5,33 \\
\hline ЮФО & 67,05 & 67,14 & 70,65 & 1,05 & 3,60 \\
\hline СКФО & $(\ldots)$ & 69,93 & 72,62 & $1,05^{*}$ & $2,69 *$ \\
\hline ПФО & 65,66 & 65,29 & 69,24 & 1,05 & 3,58 \\
\hline УФО & 64,75 & 65,15 & 69,42 & 1,07 & 4,67 \\
\hline ДФО & 64,03 & 62,70 & 67,72 & 1,06 & 3,69 \\
\hline
\end{tabular}

Примечания. 1. * - изменение продолжительности жизни по округу приведено за период 2005-2011 гг. 2. Здесь и далее приняты сокращения: РФ - Российская Федерации, ЦФО Центральный федеральный округ, СЗФО - Северо-Западный ФО, ЮФО - Южный федеральный округ, СКФО - Северо-Кавказский федеральный округ, ПФО - Приволжский федеральный округ, УФО - Уральский федеральный округ, СФО - Сибирский федеральный округ, ДФО - Дальневосточный федеральный округ.

Источник: [12].

В целом по Российской Федерации продолжительность жизни за период 2000-2011 гг. увеличилась на 4,56 года и составила 69,83 года для обоих полов. Наиболее высокое значение показателя традиционно отмечается в регионах Северного Кавказа. До выделения в отдельный федеральный округ они обеспечивали преимущество ЮФО, а затем - лидерство СКФО. Прирост показателя за рассматриваемый период в целом по РФ составил 7\%, более высокое значение было отмечено в ЦФО и СЗФО, в которых продолжительность жизни увеличилась на 5,66 и 5,33 года соответственно. Среди всех федеральных округов ДФО имеет самые низкие показатели, как по величине продолжительности жизни, так и по ее абсолютным и относительным темпам изменения. За одиннадцать лет продолжительность жизни в регионе увеличилась 
только на 2,49 года и составила $104 \%$ от уровня 2000 г. При этом в самом федеральном округе показатели отдельных субъектов РФ сильно дифференцированы. Только в Республике Саха (Якутия), Приморском и Хабаровском краях рост продолжительности жизни превысил средний по Дальнему Востоку уровень, а в Чукотском автономном округе показатель снизился более чем на 5 лет.

Увеличению продолжительности жизни в целом способствует рост расходов, выделяемых на финансирование здравоохранения. Несмотря на принятую в России социально-страховую модель, предполагающую одноканальное финансирование медицинской помощи в рамках гарантированного государством объема за счет средств обязательного медицинского страхования (ОМС), подавляющая часть финансовых средств (порядка 50\%) поступает из бюджетов различного уровня [13; 14].

За период 2003-2012 гг. расходы консолидированных бюджетов РФ на развитие здравоохранения в среднем по стране увеличились в 5,3 раза. В субъектах РФ Дальнего Востока темпы роста были несколько ниже, за исключением Камчатского края, но вместе с тем демонстрировали положительную динамику (табл. 2).

Таблица 2

Расходы консолидированных бюджетов субъектов РФ на здравоохранение

\begin{tabular}{l|c|c|c|c|c|c|c|c}
\hline \multirow{2}{*}{\multicolumn{1}{c|}{ Территория }} & \multicolumn{5}{|c|}{ Млн руб. } & \multicolumn{4}{c}{ В \% от ВРП } \\
\cline { 1 - 10 } & 2003 & 2005 & 2009 & 2012 & 2003 & 2005 & 2009 & 2011 \\
\hline $\begin{array}{l}\text { Республика Саха } \\
\text { Якутия) }\end{array}$ & 4843,9 & 7077,1 & 8574,7 & 17601,2 & 3,64 & 5,32 & 6,45 & 11,38 \\
\hline Камчатский край & 1063,5 & 2029,5 & 3797,3 & 7633,7 & 0,80 & 1,53 & 2,86 & 5,33 \\
\hline Приморский край & 3320,8 & 4906,4 & 7651,5 & 13273,4 & 2,50 & 3,69 & 5,75 & 10,17 \\
\hline Хабаровский край & 3742,2 & 5861,1 & 9862,4 & 14935 & 2,81 & 4,41 & 7,42 & 9,90 \\
\hline Амурская область & 1999,5 & 3262 & 5954 & 9233,1 & 1,50 & 2,45 & 4,48 & 6,59 \\
\hline Магаданская область & 1048,3 & 1492,6 & 3179,8 & 5377,9 & 0,79 & 1,12 & 2,39 & 3,06 \\
\hline Сахалинская область & 2087,8 & 3193,9 & 8725,5 & 11165 & 1,57 & 2,40 & 6,56 & 7,24 \\
\hline $\begin{array}{l}\text { Еврейская } \\
\text { автономная область }\end{array}$ & 403,3 & 611,5 & 1241 & 1469,1 & 0,30 & 0,46 & 0,93 & 1,37 \\
\hline $\begin{array}{l}\text { Чукотский } \\
\text { автономный округ }\end{array}$ & 827,8 & 1361,3 & 604,6 & 2417,8 & 0,62 & 1,02 & 0,45 & 1,52 \\
\hline
\end{tabular}

Источник: составлено по: [4; 12].

Считается, что существует определенная взаимосвязь между удельным весом расходов на здравоохранение в ВВП/ВРП и показателями здоровья населения. В развитых странах норма финансирования здравоохранения (из всех источников), обеспечивающая повышение продолжительности жизни, 
№ 42013

принята на уровне 10\% ВВП [1, с. 8]. В 2012 г. в целом по России удельный вес расходов на здравоохранение в ВВП составил 2,7\%, сократившись относительно 2010 г. на 0,5 п. п. В большинстве дальневосточных субъектов РФ этот показатель превышает среднероссийский уровень и имеет тенденцию к росту. Значительное увеличение доли расходов на здравоохранение в ВРП отмечается в Республике Саха (Якутия), Приморском и Хабаровском краях, Сахалинской области.

Основной статьей расходов консолидированных бюджетов, выделяемых на развитие здравоохранения, является выполнение Территориальной программы государственных гарантий оказания населению бесплатной медицинской помощи (ТПГГ), ежегодно принимаемой на уровне субъектов РФ в соответствии с установленными в Программе государственных гарантий перечнями видов, объемов и форм предоставления бесплатной медицинской помощи [7].

Самый значительный в стране уровень расходов на выполнение территориальных программ отмечается на Дальнем Востоке, что обусловлено как более высокими нормативами предоставления услуг, так и удорожающими стоимость услуг факторами. По данным за период 2008-2012 гг, рост подушевого финансирования в целом по стране составил 1,45 раза, в ДФО - 1,56. Более высокие темпы были зафиксированы только в ЮФО. При этом увеличение финансирования ТПГГ за счет средств ОМС в ДФО превысило показатели всех федеральных округов, составив 2,13 раза (табл. 3).

Таблица 3

Выполнение Территориальной программы государственных гарантий

\begin{tabular}{|c|c|c|c|c|c|c|c|c|}
\hline \multirow[b]{2}{*}{ Территория } & \multicolumn{2}{|c|}{2008} & \multicolumn{2}{|c|}{2010} & \multicolumn{2}{|c|}{2012} & \multicolumn{2}{|c|}{$2012 / 2008$} \\
\hline & $\begin{array}{l}\text { расходы } \\
\text { на ТПГГ }\end{array}$ & $\begin{array}{c}\text { в т. ч. } \\
\text { из } \\
\text { средств } \\
\text { ОМС }\end{array}$ & $\begin{array}{l}\text { расходы } \\
\text { на ТПГГ }\end{array}$ & $\begin{array}{c}\text { в т. ч. } \\
\text { из } \\
\text { средств } \\
\text { ОМС }\end{array}$ & $\begin{array}{l}\text { расходы } \\
\text { на ТПГГ }\end{array}$ & $\begin{array}{c}\text { в т. ч. } \\
\text { из } \\
\text { средств } \\
\text { ОМС }\end{array}$ & $\begin{array}{l}\text { расходы } \\
\text { на ТПГГ }\end{array}$ & $\begin{array}{l}\text { в т. ч. } \\
\text { из } \\
\text { средств } \\
\text { ОМС }\end{array}$ \\
\hline РФ & 6312,8 & 2906,5 & 7273,6 & 3661,6 & 9133,4 & 5142,7 & 1,45 & 1,77 \\
\hline ЦФО & 7714,4 & 3369,3 & 8785,6 & 4206,8 & 11116,6 & 4726,5 & 1,44 & 1,40 \\
\hline СЗФО & 7103,9 & 3146,5 & 7862,5 & 4163,8 & 9802,7 & 6098,7 & 1,38 & 1,94 \\
\hline ЮФО & 4086,4 & 2139 & 5214,6 & 2659,7 & 6869,9 & 4160,9 & 1,68 & 1,95 \\
\hline СКФО & $(\ldots)$ & $(\ldots)$ & 4183,9 & 2543,6 & 5100,4 & 3820,3 & $1,22 *$ & $1,50^{*}$ \\
\hline ПФО & 4724,6 & 2649,5 & 5766,6 & 3381,6 & 7056,5 & 4899,1 & 1,49 & 1,85 \\
\hline УФО & 8620,2 & 3114,7 & 9077,8 & 3667,4 & 11805,9 & 6294,3 & 1,37 & 2,02 \\
\hline СФО & 5996,5 & 2800 & 6860,4 & 3507,8 & 8476 & 5414 & 1,41 & 1,93 \\
\hline ДФО & 8479,4 & 3584,6 & 10901,6 & 4917,2 & 13247 & 7627,8 & 1,56 & 2,13 \\
\hline
\end{tabular}

Примечание: * - изменение приведено за период 2010-2012 гг.

Источник: [12]. 
Помимо абсолютных объемов финансирования территориальных программ и темпов их изменения, Дальний Восток также лидирует по показателям обеспеченности населения медицинской инфраструктурой и персоналом. В 2012 г. численность врачей на 10 тыс. чел. населения Дальнего Востока составила 56,2 при среднероссийской 49,1; среднего медицинского персонала - 133,3 против 106,1 по России. Обеспеченность населения больничными койками составила 112,5, что выше среднего по стране уровня на 22\% [12]. Высокие показатели обеспеченности во многом обусловлены темпами сокращения населения в округе, превышающими данные по другим территориям, по сравнению с темпами сокращения численности медицинского персонала и инфраструктуры.

Таким образом, на Дальнем Востоке сложилась парадоксальная ситуация, когда высокому уровню финансовой и инфраструктурной обеспеченности соответствуют низкие показатели продолжительности жизни населения. Для объяснения этого противоречия необходимо определить систему ограничений, сдерживающую получение адекватных затраченным средствам результатов: демографических, социально-экономических и пространственных.

Демографические ограничения. Изменение продолжительности жизни как показателя, рассчитанного на основании таблиц смертности, находится в непосредственной зависимости от младенческой смертности и смертности лиц трудоспособного возраста, в особенности мужчин, оказывающих значительное сдерживающее воздействие на увеличение продолжительности жизни.

В ДФО младенческая смертность традиционно превышает среднероссийский уровень и является одной из самых высоких в стране. Единственным федеральным округом, в котором показатель выше, является СКФО, что может быть связано как с погрешностями статистического учета, так и с территориальными особенностями размещения населения, когда подавляющая часть проживает в горных селениях, медицинская помощь в которых малодоступна (табл. 4).

Таблица 4

Младенческая смертность на 1000 рождений

\begin{tabular}{l|c|c|c|c|c|c|c}
\hline Территория & 2000 & 2003 & 2005 & 2007 & 2009 & 2011 & $2011 / 2000$ \\
\hline РФ & 15,3 & 12,4 & 11,0 & 9,4 & 8,1 & 7,4 & 0,48 \\
\hline ЦФО & 13,6 & 11,6 & 10,0 & 7,8 & 7,3 & 6,5 & 0,48 \\
\hline СЗФО & 12,8 & 10,4 & 9,4 & 7,2 & 6,2 & 5,4 & 0,42 \\
\hline ЮФО & 16,9 & 12,2 & 11,4 & 10,0 & 7,9 & 7,1 & 0,42 \\
\hline СКФО & 18,2 & 13,3 & 13,0 & 13,5 & 12,7 & 13,0 & 0,71 \\
\hline ПФО & 14,4 & 12,2 & 10,5 & 8,9 & 7,2 & 6,3 & 0,44 \\
\hline УФО & 15,4 & 11,7 & 10,0 & 8,3 & 7,1 & 6,6 & 0,43 \\
\hline СФО & 17,6 & 13,9 & 12,3 & 10,5 & 9,1 & 7,8 & 0,44 \\
\hline ДФО & 18,6 & 15,9 & 13,5 & 12,1 & 10,5 & 9,1 & 0,49 \\
\hline
\end{tabular}

Источник: [12]. 
№ 42013

За период 2000-2011 гг. сокращение младенческой смертности во всех федеральных округах составило более $50 \%$ (кроме СКФО). В ДФО снижение младенческой смертности было сравнимо со среднероссийскими темпами.

При сопоставимой с общероссийской динамикой изменения младенческой смертности ДФО опережает все федеральные округа по показателям смертности мужчин трудоспособного возраста. Если в 2000 г. показатели ДФО были ниже не только среднероссийского уровня, но и других федеральных округов (за исключением ЮФО и ПФО), то к 2011 г. смертность дальневосточных мужчин превысила среднероссийский уровень на 24\%. Это означает, что наиболее значимым фактором, определяющим величину продолжительности жизни, является смертность мужчин трудоспособного возраста.

Структура причин смертности идентична для всех территорий страны, наиболее значимые из них - заболевания системы кровообращения, новообразования и внешние причины. Вместе с тем, динамика смертности мужчин трудоспособного возраста на Дальнем Востоке, единственном среди других регионов страны, отрицательная. Увеличение смертности отмечается практически по всем группам заболеваний, за исключением инфекционных и паразитарных, а также от внешних причин. Наибольший рост смертности зафиксирован по причине заболеваний системы кровообращения $-17 \%$, органов дыхания $-16 \%$ и органов пищеварения $-61 \%$, что значительно превышает показатели других территорий (табл. 5).

Таблица 5

Изменение смертности мужчин трудоспособного возраста за период 2000-2011 гг., \%

\begin{tabular}{l|c|c|c|c|c|c|c}
\hline Территория & $\begin{array}{c}\text { От всех } \\
\text { причин }\end{array}$ & $\begin{array}{c}\text { Инфек- } \\
\text { и парнази- } \\
\text { тарные }\end{array}$ & $\begin{array}{c}\text { Новооб- } \\
\text { разова- } \\
\text { ния }\end{array}$ & $\begin{array}{c}\text { Болезни } \\
\text { системы } \\
\text { кровообра- } \\
\text { щения }\end{array}$ & $\begin{array}{c}\text { Болезни } \\
\text { органов } \\
\text { дыхания }\end{array}$ & $\begin{array}{c}\text { Болезни } \\
\text { органов } \\
\text { пище- } \\
\text { варения }\end{array}$ & $\begin{array}{c}\text { Внешние } \\
\text { причины }\end{array}$ \\
\hline РФ & 0,81 & 0,90 & 0,98 & 0,92 & 0,84 & 1,42 & 0,60 \\
\hline ЦФО & 0,71 & 0,67 & 0,86 & 0,80 & 0,67 & 1,27 & 0,50 \\
\hline СЗФО & 0,76 & 0,98 & 0,96 & 0,84 & 0,71 & 1,53 & 0,54 \\
\hline ЮФО & 0,90 & 0,82 & 1,08 & 1,07 & 1,08 & 1,33 & 0,64 \\
\hline СКФО & $(\ldots)$ & $(\ldots)$ & $(\ldots)$ & $(\ldots)$ & $(\ldots)$ & $(\ldots)$ & $(\ldots)$ \\
\hline ПФО & 0,90 & 1,11 & 1,03 & 1,02 & 1,01 & 1,74 & 0,67 \\
\hline СФО & 0,82 & 1,32 & 1,11 & 0,96 & 0,82 & 1,63 & 0,59 \\
\hline ДФО & 0,90 & 0,97 & 1,13 & 1,06 & 0,99 & 1,32 & 0,71 \\
\hline
\end{tabular}

Источник: [12]. 
Таким образом, изменение уровня смертности показывает, что наиболее значительный рост отмечается по так называемым предотвратимым заболеваниям, зависящим от качества и доступности услуг, предоставляемых в рамках системы здравоохранения.

Воздействие на высокие показатели смертности населения трудоспособного возраста оказывает половозрастная структура населения Дальнего Востока. В силу особенностей заселения региона в период хозяйственного освоения удельный вес трудоспособного населения в возрастной структуре намного превышает значения других территорий страны. Несмотря на характерную для всех регионов тенденцию перераспределения удельных весов отдельных возрастных групп в пользу увеличения населения старше трудоспособного возраста, доля трудоспособного населения в ДФО остается самой высокой в стране. В разрезе полового состава населения удельный вес мужчин трудоспособного возраста также самый высокий в стране и достигает $69 \%$ (табл. б).

Таблица 6

Изменение численности и возрастной структуры населения

\begin{tabular}{l|c|c|c|c|c|c|c|c|c}
\hline \multirow{2}{*}{ Территория } & \multicolumn{3}{|c}{$\begin{array}{c}\text { Среднегодовая численность } \\
\text { населения, тыс. чел. }\end{array}$} & \multicolumn{3}{c}{ Возрастная структура населения, \% } \\
\cline { 5 - 11 } & 2000 & 2012 & $\begin{array}{c}\text { прирост/ } \\
\text { снижение }\end{array}$ & 1 & 2 & 3 & 1 & 2 & 3 \\
\hline РФ & 146596,9 & 143201,7 & 0,98 & 19,4 & 60,2 & 20,4 & 16,6 & 60,5 & 22,9 \\
\hline ЦФО & 38201,4 & 38608,3 & 1,01 & 16,5 & 59,9 & 23,6 & 14,3 & 60,4 & 25,4 \\
\hline СЗФО & 14261,2 & 13688,9 & 0,96 & 17,6 & 61,6 & 20,8 & 14,8 & 61,0 & 24,2 \\
\hline ЮФО & 14078,8 & 13897,1 & 0,99 & 19,3 & 58,6 & 22,1 & 16,4 & 59,5 & 24,1 \\
\hline СКФО & 8673,4 & 9516,8 & 1,10 & 27,3 & 57,2 & 15,5 & 23,9 & 60,5 & 15,6 \\
\hline ПФО & 31617,4 & 29791,8 & 0,94 & 20,0 & 59,3 & 20,7 & 16,6 & 60,1 & 23,4 \\
\hline УФО & 12493,3 & 12170,5 & 0,97 & 20,2 & 61,8 & 18,0 & 17,9 & 61,1 & 21,0 \\
\hline СФО & 20398,7 & 19269,6 & 0,94 & 20,9 & 61,1 & 18,0 & 18,3 & 60,6 & 21,1 \\
\hline ДФО & 6872,7 & 6258,7 & 0,91 & 21,0 & 64,2 & 14,8 & 17,8 & 62,3 & 19,9 \\
\hline
\end{tabular}

Примечание: 1 - население моложе трудоспособного возраста; 2 - население в трудоспособном возрасте; 3 - население старше трудоспособного возраста.

Источник: [12].

Социально-экономические ограничения. На фоне существенного роста финансирования здравоохранения отмечается опережающий рост сегмента платных медицинских услуг [12; 15]. В настоящее время, несмотря на бесплатный характер медицинской помощи, предоставляемой в рамках государственных гарантий, население зачастую вынуждено оплачивать ее получение за счет личных средств в силу существующих ограничений (отсутствия специалиста, длительного ожидания записи на прием и т. д.) [6; 8]. В 2012 г. доля 
№ 42013

расходов домохозяйств на оплату медицинских услуг составила в целом по стране 5,3\%, увеличившись по сравнению с 2004 г. на 1,5 п. п. На Дальнем Востоке уровень расходов населения на оплату медицинской помощи ниже среднероссийского и составляет 4,6\%. Однако однозначно оценить данный факт как показатель более низкого уровня личных расходов населения на оплату медицинских услуг вследствие удовлетворения потребительского спроса в рамках установленных государством гарантий нельзя.

В связи с тем, что в последние годы широкое распространение получил медицинский туризм, когда население Дальнего Востока предпочитает получать широкий комплекс медицинских услуг в странах Северо-Восточной Азии, можно предположить, что значительная часть денежных средств, предназначенных для получения медицинских услуг, тратится за пределами России и не попадает под статистический учет доходов и расходов домохозяйств. По оценкам экспертов, поток туристов только в Республику Корея возрастает на $10 \%$ ежегодно. При этом основная масса $(70 \%)$ приезжающих в эту страну за получением высококачественной, квалифицированной медицинской помощи - это жители Дальнего Востока [3; 10; 11$].$

Наглядным свидетельством существующих ограничений получения медицинской помощи в рамках государственного сектора является рост объема платных медицинских услуг. В целом по стране за период 2000-2012 гг. объем рынка увеличился более чем в 12 раз. При этом на Дальнем Востоке темп роста превысил как среднероссийский, так и показатели других регионов (за исключением СЗФО) и составил практически 16 раз (табл. 7).

Таблица 7

Объем платных медицинских услуг, млн руб.

\begin{tabular}{l|c|c|c|c|c|c}
\hline \multicolumn{1}{|c|}{ Территория } & 2000 & 2005 & 2010 & 2011 & 2012 & $2012 / 2000$ \\
\hline РФ & 27448 & 109756 & 250474 & 286058 & 333895 & 12,16 \\
\hline ЦФО & 9342 & 31716 & 75627 & 85073 & 102626 & 10,99 \\
\hline СЗФО & 2854 & 14930 & 36317 & 42846 & 47492 & 16,64 \\
\hline ЮФО & 1802 & 7356 & 18274 & 21270 & 24287 & 13,48 \\
\hline СКФО & 734 & 2320 & 7438 & 9937 & 11812 & 16,09 \\
\hline ПФО & 4712 & 18759 & 49838 & 55682 & 64182 & 13,62 \\
\hline УФО & 2658 & 11246 & 25807 & 28934 & 32910 & 12,38 \\
\hline СФО & 4303 & 18542 & 25457 & 28347 & 33987 & 7,90 \\
\hline ДФО & 1042 & 4885 & 11716 & 13969 & 16599 & 15,93 \\
\hline
\end{tabular}

Источник: [12].

Значительному росту объемов платных медицинских услуг, помимо увеличения потребительского спроса, способствуют и ценовые факторы. Для определения ценовой доступности медицинских услуг и динамики ее из- 
менений за период 2003-2011 гг. были сопоставлены данные об изменении доходов (среднедушевых, заработной платы и пенсий), стоимости условно принятого набора медицинских услуг (первичный прием врача и общий анализ крови) и покупательной способности доходов населения. Полученные в разрезе дальневосточных субъектов РФ оценки показывают, что, несмотря на более высокий уровень номинальных доходов населения, их покупательная способность, измеренная количеством условных наборов медицинских услуг, ниже, чем в среднем по России, и существенно дифференцирована внутри ДФО. Во-первых, рост стоимости условно принятого набора услуг во всех регионах Дальнего Востока превышает среднероссийский уровень. Во-вторых, в шести из девяти субъектах (Республике Саха (Якутия), Приморском крае, Амурской, Магаданской, Еврейской автономной областях и Чукотском автономном округе) рост стоимости условного набора услуг превысил рост среднедушевых доходов населения и заработной платы (за исключением Республики Саха (Якутия). Соотношение темпов роста стоимости набора и пенсий только в двух регионах было отрицательным (Амурской области и Чукотском автономном округе). В-третьих, покупательная способность доходов населения снижается в пяти дальневосточных субъектах РФ, как по среднедушевым доходам, так и по заработной плате, тогда как в целом по стране ценовая доступность медицинских услуг увеличивается (табл. 8).

Таблица 8

Изменение ценовой доступности медицинских услуг, 2011/2003 гг., раз

\begin{tabular}{|c|c|c|c|c|c|c|c|}
\hline \multirow[b]{2}{*}{ Территория } & \multicolumn{3}{|c|}{ Доходы } & \multirow{2}{*}{$\begin{array}{l}\text { Стои- } \\
\text { мость } \\
\text { услуг }\end{array}$} & \multicolumn{3}{|c|}{$\begin{array}{c}\text { Покупательная } \\
\text { способность доходов }\end{array}$} \\
\hline & СДД & $\begin{array}{c}\text { зара- } \\
\text { ботная } \\
\text { плата }\end{array}$ & пенсии & & СДД & $\begin{array}{c}\text { зара- } \\
\text { ботная } \\
\text { плата }\end{array}$ & пенсии \\
\hline РФ & 4,01 & 4,25 & 4,73 & 3,27 & 1,23 & 1,30 & 1,45 \\
\hline Республика Саха (Якутия) & 3,11 & 3,51 & 5,21 & 3,32 & 0,94 & 1,06 & 1,57 \\
\hline Камчатский край & 4,08 & 3,81 & 5,23 & 3,49 & 1,17 & 1,09 & 1,50 \\
\hline Приморский край & 4,51 & 4,22 & 4,76 & 5,86 & 0,77 & 0,72 & 0,81 \\
\hline Хабаровский край & 3,83 & 3,55 & 4,96 & 3,35 & 1,14 & 1,06 & 1,48 \\
\hline Амурская область & 4,62 & 4,08 & 4,81 & 5,96 & 0,77 & 0,68 & 0,81 \\
\hline Магаданская область & 3,72 & 4,47 & 5,38 & 4,97 & 0,75 & 0,90 & 1,08 \\
\hline Сахалинская область & 4,20 & 4,16 & 5,23 & 3,37 & 1,25 & 1,23 & 1,55 \\
\hline Еврейская автономная область & 4,07 & 4,24 & 4,71 & 6,88 & 0,59 & 0,62 & 0,68 \\
\hline Чукотский автономный округ & 3,15 & 3,09 & 5,85 & 24,61 & 0,13 & 0,13 & 0,24 \\
\hline
\end{tabular}

Примечание: СДД - среднедушевые денежные доходы.

Источник: рассчитано по [12]. 
№ 42013

Пространственные ограничения. Под пространственными ограничениями (пространственной доступностью) в данном исследовании понимается сочетание характеристик, определяющих доступ населения к получению своевременной медицинской помощи, к числу которых относятся: плотность населенных пунктов, плотность медицинских учреждений, плотность населения, плотность автомобильных дорог, обеспеченность населенных пунктов медицинскими учреждениями.

Формирование оптимальной сети медицинских учреждений на основе нормирования потребностей в привязке к численности населения фактически привело к далеко не оптимальным результатам с точки зрения пространственной доступности получения медицинских услуг [2].

Ситуация в ДФО, лидирующем по показателям обеспеченности населения медицинским персоналом и инфраструктурой, кардинально меняется при учете пространственных характеристик.

Плотность больничных учреждений в округе в 2012 г. составила только 0,07 на 1000 км² при среднероссийском показателе 0,36; амбулаторно-поликлинических - самая низкая в стране и составляет 0,16 и 0,97 соответственно. Снижение плотности распределения медицинских учреждений характерно для всех регионов, что вызвано общим сокращением числа медицинских учреждений. Однако ДФО лидирует по темпам ее изменения: на $50 \%$ по числу больниц на 1000 км² и на 41\% по амбулаторно-поликлиническим учреждениям (табл. 9).

Плотность медицинских учреждений, ед. на 1000 км²

Таблица 9

\begin{tabular}{l|c|c|c|c|c|c}
\hline \multirow{2}{*}{ Территория } & \multicolumn{3}{|c|}{ Больничные учреждения } & \multicolumn{3}{c}{ Амбулаторно-поликлинические } \\
& 2005 & 2012 & $2012 / 2005$ & 2005 & 2012 & $2012 / 2005$ \\
\hline & 0,55 & 0,36 & 0,65 & 1,27 & 0,97 & 0,76 \\
\hline РФ & 3,19 & 2,21 & 0,69 & 8,84 & 7,02 & 0,79 \\
\hline СФО & 0,49 & 0,34 & 0,69 & 1,14 & 1,09 & 0,96 \\
\hline ЮФО & 1,82 & 1,26 & 0,69 & 3,99 & 3,74 & 0,94 \\
\hline СКФО & 3,11 & 2,21 & 0,71 & 6,97 & 4,37 & 0,63 \\
\hline ПФО & 2,01 & 1,22 & 0,61 & 4,18 & 3,02 & 0,72 \\
\hline УФО & 0,37 & 0,32 & 0,85 & 0,87 & 0,67 & 0,77 \\
\hline СФО & 0,33 & 0,19 & 0,59 & 0,71 & 0,48 & 0,68 \\
\hline ДФО & 0,13 & 0,07 & 0,50 & 0,27 & 0,16 & 0,59 \\
\hline
\end{tabular}

Источник: рассчитано по [12].

Усугубляют снижение пространственной доступности медицинских услуг на Дальнем Востоке параметры плотности населения, населенных пунктов и автомобильных дорог. Регион среди других территорий страны остается наи- 
менее заселенным. При общей плотности населения по России в 8,38 чел.

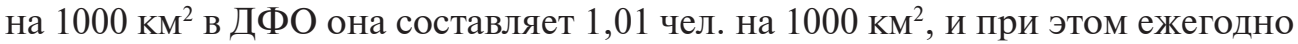
снижается. Плотность населенных пунктов, измеренная как соотношение числа муниципальных образований (городских округов, поселений городского и сельского типа) с площадью территории, также снижается, что связано с проводимыми преобразованиями административно-территориального деления на уровне местного самоуправления. При высокой разреженности мест проживания плотность автомобильных дорог как связующего их элемента самая низкая в стране, причем только в ДФО протяженность автодо-

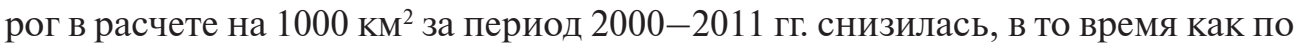
всем остальным округам увеличилась (табл. 10).

Таблица 10

\section{Пространственные характеристики}

\begin{tabular}{|c|c|c|c|c|c|c|c|c|c|}
\hline \multirow{2}{*}{ Территория } & \multicolumn{3}{|c|}{$\begin{array}{c}\text { Плотность населения, } \\
\text { чел. на } 1000 \text { км² }^{2}\end{array}$} & \multicolumn{3}{|c|}{$\begin{array}{c}\text { Плотность населенных } \\
\text { пунктов*, ед. на } 1000 \text { км²}^{2}\end{array}$} & \multicolumn{3}{|c|}{$\begin{array}{c}\text { Плотность автодорог, } \\
\text { км на } 1000 \text { км}^{2}\end{array}$} \\
\hline & 2005 & 2012 & $\begin{array}{l}2012 / \\
2005\end{array}$ & 2005 & 2012 & $\begin{array}{l}2012 / \\
2005\end{array}$ & 2000 & 2011 & $\begin{array}{r}2011 / \\
2000\end{array}$ \\
\hline РФ & 8,37 & 8,38 & 1,001 & 1,58 & 1,23 & 0,78 & 44 & 49 & 1,11 \\
\hline ЦФО & 57,60 & 59,38 & 1,031 & 10,34 & 6,82 & 0,66 & 242 & 262 & 1,08 \\
\hline СЗФО & 8,11 & 8,11 & 1,001 & 1,23 & 0,85 & 0,69 & 51 & 54 & 1,06 \\
\hline ЮФО & 54,18 & 33,02 & 0,609 & 8,02 & 3,80 & 0,47 & 155 & 171 & 1,10 \\
\hline СКФО & $(\ldots)$ & 55,85 & $(\ldots)$ & $(\ldots)$ & 9,38 & $(\ldots)$ & 228 & 356 & 1,56 \\
\hline ПФО & 29,52 & 28,73 & 0,973 & 7,26 & 5,48 & 0,76 & 168 & 178 & 1,06 \\
\hline УФО & 6,74 & 6,69 & 0,993 & 0,94 & 0,69 & 0,73 & 32 & 34 & 1,06 \\
\hline СФО & 3,84 & 3,75 & 0,976 & 0,78 & 0,74 & 0,95 & 25 & 30 & 1,20 \\
\hline ДФО & 1,06 & 1,01 & 0,953 & 0,24 & 0,20 & 0,83 & 7,5 & 7,2 & 0,96 \\
\hline
\end{tabular}

Примечание. * В число населенных пунктов включались муниципальные образования: городские округа, городские и сельские поселения.

Источник: рассчитано по [12].

Фактическим результатом действующего в настоящее время подхода к определению потребностей в медицинских учреждениях исключительно с привязкой к численности населения является сворачивание сети лечебных учреждений. Темпы сокращения обеспеченности населенных пунктов медицинскими учреждениями на Дальнем Востоке превосходят показатели других территорий страны как по больничным, так и по амбулаторно-поликлиническим учреждениям (табл. 11).

В разрезе городской и сельской местности изменение пространственной доступности медицинских услуг более показательно (табл. 12). 
2013

Таблица 11

Обеспеченность медицинскими учреждениями в расчете на 1 населенный пункт

\begin{tabular}{l|c|c|c|c|c|c}
\hline \multirow{2}{*}{ Территория } & \multicolumn{3}{|c|}{ Больничные учреждения } & \multicolumn{3}{c}{ Амбулаторно-поликлинические } \\
& 2005 & 2012 & $2012 / 2005$ & 2005 & 2012 & $2012 / 2005$ \\
\cline { 2 - 7 } & 0,35 & 0,29 & 0,83 & 0,81 & 0,79 & 0,97 \\
\hline РФ & 0,31 & 0,32 & 1,05 & 0,85 & 1,03 & 1,20 \\
\hline ЦФО & 0,40 & 0,40 & 1,00 & 0,93 & 1,29 & 1,39 \\
\hline СЗФО & 0,23 & 0,33 & 1,46 & 0,50 & 0,98 & 1,98 \\
\hline ЮФО & $(\ldots)$ & 0,24 & $(\ldots)$ & $(\ldots)$ & 0,47 & $(\ldots)$ \\
\hline ПФОО & 0,28 & 0,22 & 0,81 & 0,58 & 0,55 & 0,96 \\
\hline УФО & 0,40 & 0,46 & 1,16 & 0,93 & 0,97 & 1,05 \\
\hline СФО & 0,42 & 0,26 & 0,62 & 0,91 & 0,65 & 0,71 \\
\hline ДФО & 0,55 & 0,33 & 0,60 & 1,12 & 0,79 & 0,71 \\
\hline
\end{tabular}

Источник: рассчитано по [12].

Таблица 12

Обеспеченность медицинскими учреждениями в расчете на 1 населенный пункт, в разрезе городской и сельской местности

\begin{tabular}{l|c|c|c|c|c|c|c|c}
\hline \multirow{2}{*}{ Территория } & \multicolumn{4}{|c|}{ Больничные учреждения } & \multicolumn{3}{c}{ Амбулаторно-поликлинические } \\
& \multicolumn{2}{|c|}{2010} & \multicolumn{2}{c}{2012} & \multicolumn{2}{c}{2010} & \multicolumn{2}{c}{2012} \\
\cline { 2 - 11 } & город & село & город & село & город & село & город & село \\
\hline \multirow{2}{*}{ РФ } & 2,22 & 0,07 & 2,25 & 0,06 & 6,82 & 0,02 & 7,31 & 0,013 \\
\hline ЦФО & 2,11 & 0,05 & 2,12 & 0,04 & 7,19 & 0,02 & 7,54 & 0,007 \\
\hline СЗФО & 1,95 & 0,05 & 1,96 & 0,05 & 6,10 & 0,02 & 6,91 & 0,016 \\
\hline ЮФО & 3,12 & 0,10 & 3,22 & 0,09 & 11,78 & 0,02 & 12,46 & 0,019 \\
\hline СКФО & 3,00 & 0,11 & 2,93 & 0,11 & 9,32 & 0,09 & 8,52 & 0,081 \\
\hline ПФО & 2,33 & 0,05 & 2,40 & 0,04 & 6,64 & 0,00 & 7,25 & 0,000 \\
\hline УФО & 2,45 & 0,11 & 2,52 & 0,10 & 6,65 & 0,03 & 6,36 & 0,027 \\
\hline СФО & 2,29 & 0,06 & 2,32 & 0,06 & 6,39 & 0,01 & 7,31 & 0,003 \\
\hline ДФО & 1,52 & 0,09 & 1,58 & 0,08 & 4,21 & 0,02 & 4,70 & 0,009 \\
\hline
\end{tabular}

Источник: рассчитано по [9; 12].

Полученные оценки наглядно показывают различия в обеспеченности лечебными учреждениями городских и сельских населенных пунктов. На Дальнем Востоке количество больничных учреждений в городской местности самое низкое по сравнению с другими территориями, при этом в расчете на 1 сельский населенный пункт показатели превышают среднероссийский уровень. Более контрастная ситуация между городской и сельской местностью наблюдается по числу амбулаторно-поликлинических учреждений. 
При среднероссийских показателях обеспеченности городских и сельских населенных пунктов 7,31 и 0,013 соответственно, на Дальнем Востоке они составляют только 4,7 и 0,009.

Динамика изменения обеспеченности населенных пунктов медицинскими учреждениями в разрезе городской и сельской местности показывает, что на Дальнем Востоке темпы ее снижения были самые высокие в стране. Сочетание отрицательной динамики обеспеченности и изменения пространственных характеристик свидетельствует о снижении пространственной доступности медицинских услуг для населения, что наиболее сильно проявляется в сельской местности.

Проведенный анализ позволяет утверждать следующее: оценка результативности системы здравоохранения на основе официальной статистики, без учета специфики демографических, социально-экономических и пространственных характеристик регионов, дает искаженные представления о реальной ситуации в этом сегменте экономики. Наиболее остро это проявляется в регионах с высоким уровнем неоднородности экономического пространства, где возникает парадоксальная ситуация, когда высокий уровень финансирования системы здравоохранения не обеспечивает сравнимых с российским уровнем показателей здоровья населения. На основании вышеизложенного можно предположить, что использование единой для всех регионов модели здравоохранения приводит к снижению ценовой и пространственной доступности медицинских услуг для населения, невозможности достижения целевых показателей в сфере здоровья населения и, в конечном счете, неэффективности использования государственных средств.

\section{СПИСОК ЛИТЕРАТУРЫ}

1. Аганбегян А.Г. Как долго жить и оставаться здоровым // ЭКО. 2011. № 10. C. $5-13$.

2. Бочкарева В.К. Реформирование здравоохранения и обеспечение равной доступности к бесплатным медицинским услугам // ЭКО. 2011. № 10. С. 13-35.

3. Волкова $E$. Теневой рынок в госмедучреждениях и медицинский туризм тормозят развитие частной медицины Дальнего Востока. URL.: http://www.zrpress.ru/ health/dalnij-vostok_08.10.2013 (дата обращения: 09.10.2013).

4. Министерство финансов Российской Федерации. URL.: http://info.minfin.ru/ foms.php (дата обращения: 23.09.2013).

5. Оценка систем здравоохранения с позиций Всемирной организации здравоохранения // Здравоохранение. 2009. № 11. URL.: http://www.zdrav.ru/articles/practice/ detail.php?ID=76105 (дата обращения: 17.09.2013).

6. Потапчик E.Г., Селезнева Е.В., Шишкин С.В. Доступность медицинской помощи для населения (по материалам мониторинга экономических процессов в здравоохранении): препринт WP8/2011/11 / Нац. исслед. ун-т «Высшая школа экономики». М.: Изд. дом Высшей школы экономики, 2011. 36 с. 
7. Программа государственных гарантий бесплатного оказания гражданам медицинской помощи на 2013 год и на плановый период 2014 и 2015 годов: утв. Постановлением Правительства РФ от 22 октября 2012 г. № 1074. URL.: http://government.ru/ docs/7594 (дата обращения: октябрь 2013).

8. Русинова Н.Л., Панова Л.В. Доступ к услугам здравоохранения: методологические подходы и методы измерения // Журнал социологии и социальной антропологии. 2002. № 4. С. 147-163.

9. Сельское здравоохранение в России в 2012 г.: стат. сб. / Министерство здравоохранения PФ. URL.: http://www.rosminzdrav.ru/docs/mzsr/stat/47 (дата обращения: октябрь - ноябрь 2013).

10. Смирнова А. Путешествия за здоровьем // Travel Russian News. 2013. 22 октября. URL.: http://www.trn-news.ru/articles/3649 (дата обращения: октябрь 2013).

11. Тебин H. Медицинский туризм // Медицинская газета. URL.: http://www.mgzt. ru/article/1961/ (дата обращения: октябрь 2013).

12. Федеральная служба государственной статистики. URL.: http://www.gks.ru (дата обращения: июль - сентябрь 2013).

13. Шарабчиев Ю.Т. Экономические модели и реформирование здравоохранения: опыт организации различных систем управления здравоохранением // Медицинские новости. 2006. № 6. С. 61-68. URL.: http://www.mednovosti.by/journal.aspx?article=590 (дата обращения: 15.08.2013).

14. Шейман И.М. Теория и практика рыночных отношений в здравоохранении / Гос. ун-т - Высшая школа экономики. 2-е изд. М.: Изд. дом ГУ ВШЭ, 2008. 318 с.

15. Шишкин C., Потапчик E., Селезнева Е. Частный сектор здравоохранения в России: состояние и перспективы развития // Вопросы экономики. 2013. № 4. С. 94-112.

16. World Health Organization. World Health Statistics reports. URL.: http://www.who. int/gho/publications/world_health_statistics/en/index.html (дата обращения: сентябрь 2013).

\title{
SPATIAL DEFORMATION OF THE PUBLIC HEALTH SYSTEM EFFECTIVENESS
}

\author{
M.A. Gritsko, E.O. Kolbina
}

Gritsko Maria Anatolyevna - Ph. D. in Economics, Research Fellow. Economic Research Institute FEB RAS, 153 Tikhookeanskaya Street, Khabarovsk, Russia, 680042. E-mail: gritsko@ecrin.ru.

Kolbina Ekaterina Olegovna - Ph. D. in Economics, Research Fellow. Economic Research Institute FEB RAS, 153 Tikhookeanskaya Street, Khabarovsk, Russia, 680042. E-mail: skripnikk@gmail.com.

Using official statistics the authors assess the performance of the public health system in the context of federal districts of the Russian Federation. The study shows that despite the highest level of funding among all federal districts, effectiveness of the public health system in the Far Eastern district remains the lowest in the country, both in absolute terms and measured by rates of their changes. Low efficiency rate can be explained when various constraints are taken into account: demographic, socio-economic and spatial. Among the demographic constraints the authors point towards high mortality rate of working-age males in the region that is highest among all districts, especially in preventable diseases. Under the socio-economic limitations the authors understand low affordability of medical services for the population of almost all subjects of FEFD. Spatial constraints include low population, settlements and road network densities due to historical patterns of settlement. The analysis suggests that, firstly, ignoring the restrictions forms a distorted view of 
the actual situation in this sector; and secondly, the use of a single healthcare model for all regions reduces affordability and spatial accessibility of medical services for the population, prevents achievement of public health targets and efficient use of public funds.

Keywords: The public health system effectiveness, life expectancy, infant mortality, mortality of ablebodied men, restrictions' system, affordability, spatial accessibility.

\section{REFERENCES}

1. Aganbegyan A.G. How Long to Live and to be Healthy. Eco - Eco, 2011, no. 10, pp. 5-13. (In Russian).

2. Bochkareva V.K. Reformation of the Health Care System and Ensuring Equal Access to Free of Charge Health Services. Eco - Eco, 2011, no. 10, pp. 13-35. (In Russian).

3. Volkova E. The Shadow Market in State Medical Institutions and Medical Tourism Hamper the Development of Private Medicine in the Far East. Available at: http://www.zrpress. $\mathrm{ru} /$ health/dalnij-vostok 08.10.2013 (accessed 09 October 2013). (In Russian).

4. The Ministry of Finance of the Russian Federation. Available at: http://info.minfin.ru/ foms.php (accessed 23 September 2013). (In Russian).

5. Assessment of Health Systems from the Position of the World Health Organization. Zdravookhranenie [Healthcare], 2009, no. 11. Available at: http://www.zdrav.ru/articles (accessed 17 September 2013). (In Russian).

6. Potapchik E.G., Selezneva E.V., Shishkin S.V. Accessibility of Medical Care for the Population (Based on Monitoring of Economic Developments in Health System): Working paper WP8/2011/11. Moscow: State University - Higher School of Economics, 2011, 36 p. (In Russian).

7. The Programme of State Guarantees of Free Provision of Health Care in 2013 and for the Planned Period 2014 and 2015: approved by Government Resolution of 22 October 2012 № 1074. Available at: http://government.ru/docs/7594 (accessed October 2013). (In Russian).

8. Rusinova N.L., Panova L.V. Access to Health Care: Methodological Approaches and Basic Measures. Zhurnal Sotsiologii i sotsialnoy Antropologii - The Journal of Sociology and Social Anthropology, 2002, no. 4, pp. 147-163. (In Russian).

9. Rural Health in Russia in 2012: statistical collection. Ministry of Health of the Russian Federation. Available at: http://www.rosminzdrav.ru/docs/mzsr/stat/47 (accessed OctoberNovember 2013). (In Russian).

10. Smirnova A. Travels for Health. Travel Russian News - Travel Russian News, 2013, 22 October. Available at.: http://www.trn-news.ru/articles/3649 (accessed October 2013). (In Russian).

11. Tebin N. Medical Tourism. Meditsinskaya Gazeta [Medical newspaper]. Available at: http://www.mgzt.ru/article/1961/ (accessed October 2013). (In Russian).

12. Federal State Statistics Service. Available at: http://www.gks.ru (accessed July - September 2013). (In Russian).

13. Sharabchiev Yu.T. The Economic Model and the Reform of Health Care: Experience of the Organization of Various Health-Care Management Systems. Meditsinskie Novosti [Medical News], 2006, no. 6, pp. 61-68. Available at: http://www.mednovosti.by/journal. aspx?article $=590$ (accessed 15 August 2013). (In Russian).

14. Sheyman I.M. Theory and Practice of Market Relations in Healthcare. Moscow: State University - Higher School of Economics, 2008, 318 p. (In Russian).

15. Shishkin S., Potapchik E., Selezneva E. Private Health Care Sector in Russia: Present State and Development Prospects. Voprosy Ekonomiki [Economic Issue], 2013, no. 4, pp. 94-112. (In Russian).

16. World Health Organization. World Health Statistics reports. Available at: http://www. who.int/gho/publications/world_health_statistics/en/index.html (accessed September 2013). 